\title{
Prostaglandin F1 Alpha Measurement
}

National Cancer Institute

\section{Source}

National Cancer Institute. Prostaglandin F1 Alpha Measurement. NCI Thesaurus. Code C103436.

The determination of the amount of the prostaglandin F1 alpha in a sample. 